Zeszyty Naukowe Szkoły Głównej Gospodarstwa Wiejskiego

Ekonomika i Organizacja Gospodarki Żywnościowej nr 113, 2016: 117-129

Monika Zielińska-Sitkiewicz

Katedra Ekonometrii i Statystyki

Szkoła Głowna Gospodarstwa Wiejskiego w Warszawie

\title{
Zastosowanie metod wielowymiarowej analizy dyskryminacyjnej do prognozowania upadłości wybranych spółek sektora spożywczego
}

\section{Wstęp}

Ocena kondycji ekonomicznej przedsiębiorstwa powinna być kluczowym elementem procesu zarządzania firmą. Ciagła zmienność otoczenia gospodarczego oraz wzrost konkurencji na rynku sprawia, że problematyka badania zagrożeń upadłością stale jest istotna. W Polsce w latach 90. XX wieku, na skutek transformacji gospodarczej pojawiły się pierwsze upadłości przedsiębiorstw, a co za tym idzie - nastapił początek prac badawczych w zakresie modeli wczesnego ostrzegania. Wyniki analiz predykcji upadłości polskich firm jako pierwsza opublikowała E. Mączyńska [Mączyńska 1994]. Metodologię konstruowania modeli dyskryminacyjnych rozwijali w kolejnych latach między innymi: J. Gajdka i D. Stos [1996], D. Hadasik [1998], D. Mejer [2000], D. Wierzba [2000], A. Hołda [2001], S. Sojak i J. Stawicki [2001], M. Gruszczyński [2003], M. Hamrol, B. Czajka, M. Piechocki [2004], B. Prusak [2005], E. Mączyńska i M. Zawadzki [2006], P. Antonowicz [2007], M. Hamrol i J. Chodakowski [2008], W. Lichota [2009], J. Kisielińska [2008, 2010].

Upadłość przedsiębiorstw rozpatruje się zarówno w aspekcie prawnym, jak i ekonomicznym. Z prawnego punktu widzenia upadłość jest ustalana sądownie. To wdrażana procedura, która ma zapewnić zaspokojenie wierzytelności, w przypadku niewypłacalności dłużnika i dotyczy całego jego majątku. Rozróżnia się: upadtość układowa, która ma na celu restrukturyzację przedsiębiorstwa i zawarcie układu z wierzycielami oraz upadłość likwidacyjna, której konsekwencja jest zbycie majątku przedsiębiorstwa upadłego i zaspokojenie wierzycieli z uzyskanych $\mathrm{w}$ ten sposób środków. W ujęciu ekonomicznym upadłość 
przedsiębiorstwa oznacza sytuację, w której firma nie jest w stanie samodzielnie kontynuować działalności bez pomocy z zewnątrz. Niekoniecznie ten stan rzeczy ujawnia się natychmiast $w$ danych finansowych.

Sektor spożywczy jest jedną $\mathrm{z}$ dominujących branż przemysłu w Polsce i według Polskiej Agencji Informacji i Inwestycji Zagranicznych generuje ponad 13\% wartości polskiego PKB. Jego właściwością jest pewna acykliczność, przez co nie jest on mocno wrażliwy na zmiany koniunktury gospodarczej. Na kondycję branży spożywczej wpływają m.in. takie czynniki, jak wahania cen surowców czy chociażby sytuacja polityczna za naszą wschodnią granicą. Kryzys gospodarki rosyjskiej i nałożone embargo na produkty rolno-spożywcze nie wywołują w Polsce dotkliwych rezultatów w ujęciu makroekonomicznym. Jednak dla wielu polskich przedsiębiorstw skutkują zawieszeniem stałego kierunku eksportowego i wpływają negatywnie na ich kondycję finansową. Jak prognozują eksperci z Coeface (por. Raport 2014) statystyki upadłościowe mogą być w najbliższym czasie zasilane bankructwami firm sektora spożywczego. Już w $2014 \mathrm{r}$. liczba upadłości przedsiębiorstw spożywczych wzrosła o 37,8\% w relacji do lat 2013 i 2012, kiedy bankructwo ogłosiło 37 jednostek (por. dane Coeface).

\section{Cel i opis badania}

Celem artykułu jest próba wykorzystania i oceny trzech polskich modeli opartych na analizie dyskryminacji w zakresie prognozowania zagrożenia upadłością 15 wybranych firm sektora spożywczego, notowanych na rynku głównym GPW w Warszawie, których rachunek zysków i strat sporządzany jest w układzie kalkulacyjnym. Analizę przeprowadzono dla lat 2008-2014.

Do badania wybrano przedsiębiorstwa: Colian Holding SA, Duda SA, Graal SA, Indykpol SA, Jago SA ${ }^{1}$, Kruszwica SA, Makarony Polskie SA, Mieszko SA, Mispol SA, Otmuchów SA, Pamapol SA, Pepees SA, Seko SA, Wawel SA oraz Wilbo SA. Działalność analizowanych spółek prowadzona jest głównie na terenie Polski. Pominięto firmy reprezentujące branżę alkoholi.

W badaniu wykorzystano metody opracowane dla rynku polskiego i wybrane w oparciu o Wzorzec Wielowymiarowego Systemu Wczesnego Ostrzegania $(W W S W O)$ dla przedsiębiorstw produkcyjnych, utworzony przez P. Antonowicza [Antonowicz 2007, s. 168]. Obliczono trzy modele dyskryminacyjne mające największą zdolność przewidywania upadłości jednostek produkcyjnych według

\footnotetext{
${ }^{1}$ Jedyna spółka w analizie z typowo handlowym profilem działalności (lody i mrożonki), włączona do badań ze względu na ogłoszoną w lutym 2012 r. upadłość układową, a w kwietniu 2012 r. upadłość likwidacyjną majątku. W dniu 24.10.2012 akcje spółki Jago SA zostały wycofane z giełdy i przedsiębiorstwo nie opublikowało sprawozdania finansowego za $2012 \mathrm{r}$.
} 
P. Antonowicza. Ponadto w analizie uwzględniono cztery jednowymiarowe wskaźniki finansowe, które wykazały najwyższy stopień wrażliwości na sygnalizację zagrożenia upadłością.

Najwyższe zdolności predykcyjne dla jednostek produkcyjnych wykazał model poznański opracowany przez trzech autorów: M. Hamrola, B. Czajkę i M. Piechockiego, ze średnią sprawnością prognozy 92,98\%. Wskaźniki finansowe użyte do konstrukcji funkcji dyskryminacyjnej mają postać:

$X_{1}=$ wynik finansowy netto/majątek całkowity,

$X_{2}=($ majątek obrotowy - zapasy $) /$ zobowiązania krótkoterminowe,

$X_{3}=$ kapitał stały/majątek całkowity,

$X_{4}=$ wynik finansowy ze sprzedaży/przychody ze sprzedaży.

Dokonując interpretacji funkcji dyskryminacyjnej:

$$
Z_{\mathrm{HCP}}=-2,368+3,562 \cdot X_{1}+1,588 \cdot X_{2}+4,288 \cdot X_{3}+6,719 \cdot X_{4}
$$

należy opierać się na następujących zasadach: $Z_{\mathrm{HCP}} \leq 0$ to przedsiębiorstwo zagrożone upadłością w perspektywie 1 roku, a jeśli $Z_{\mathrm{HCP}}>0$, to przedsiębiorstwu nie zagraża bankructwo.

Drugie miejsce według $W W S W O$ zajął model B. Prusaka $Z_{\mathrm{BP} 2}$. Przewiduje on upadłość $\mathrm{z}$ rocznym wyprzedzeniem, ze średnią sprawnością prognozy $92,36 \%$ dla przedsiębiorstw produkcyjnych.

$\mathrm{W}$ funkcji $Z_{\mathrm{BP} 2}$ użyto trzech zmiennych finansowych:

$X_{1}=($ wynik netto + amortyzacja $) /$ zobowiązania ogółem,

$X_{2}=$ koszty operacyjne/zobowiązania krótkoterminowe,

$X_{3}=$ zysk ze sprzedaży/suma bilansowa.

Oszacowany na ich podstawie liniowy model dyskryminacyjny przyjął następującą postać:

$$
Z_{\mathrm{BP} 2}=-1,8713+1,4383 \cdot X_{1}+0,1878 \cdot X_{2}+5,0229 \cdot X_{3}
$$

Interpretacji funkcji dokonuje się $\mathrm{w}$ oparciu o następujące kryteria:

$Z_{\mathrm{BP} 2}>0,2$ przedsiębiorstwo niezagrożone upadłością

$Z_{\mathrm{BP} 2}<(-0,7)$ przedsiębiorstwo zagrożone upadłością $\mathrm{w}$ perspektywie 2 lat

$Z_{\mathrm{BP} 2} \in<-0,7 ; 0,2>$ obszar niepewności, czyli ,szara strefa"

Cut-off point $=(-0,295)[$ Antonowicz 2007, s. 61-62].

$\mathrm{Z}$ niewiele niższą średnią sprawnością prognozy $92,16 \%$ dla firm produkcyjnych, na trzecim miejscu wg $W W S W O$ znalazł się model $Z_{7}$ INE PAN. Powstał on w Instytucie Nauk Ekonomicznych PAN pod kierunkiem E. Mączyńskiej. Wskaźniki finansowe użyte do konstrukcji tej funkcji mają postać:

$X_{1}=$ wynik operacyjny/wartość aktywów, 
$X_{2}=$ wartość kapitału własnego/wartość aktywów,

$X_{3}=($ wynik netto + amortyzacja $) /$ suma zobowiązań,

$X_{4}=$ aktywa obrotowe/zobowiązania krótkoterminowe.

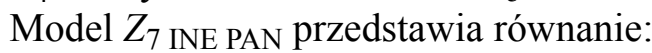

$$
Z_{7 \mathrm{INE} \mathrm{PAN}}=-1,498+9,498 \cdot X_{1}+3,566 \cdot X_{2}+2,903 \cdot X_{3}+0,452 \cdot X_{4}
$$

Jednostki gospodarcze $\mathrm{z}$ wartościami powyżej zera $\left(\mathrm{Z}_{7 \text { INE PAN }}>0\right)$ określane sa, jako te niezagrożone upadłością. $Z$ kolei przedsiębiorstwa, dla których wyniki przyjmują wartości nie większe niż zero $\left(Z_{7}\right.$ INE PAN $\left.\leq 0\right)$, to firmy zagrożone upadłością w perspektywie 1 roku [Mączyńska 2004].

Dodatkowo w opracowanym przez P. Antonowicza Wzorcu Wielowymiarowego Systemu Wczesnego Ostrzegania dla firm produkcyjnych, najbardziej wrażliwymi jednowymiarowymi predyktorami upadłości okazały się: wskaźnik udziału kapitału stałego $\mathrm{w}$ finansowaniu majątku $=($ kapitat wtasny + zobowiazania dlugoterminowe)/aktywa, wskaźnik pokrycia kosztów finansowych $=$ wynik operacyjny/koszty finansowe, wskaźnik płynności gotówkowej = (majątek obrotowy - zapasy - należności krótkoterminowe)/zobowiqzania krótkoterminowe oraz wskaźnik udziału kapitału własnego $\mathrm{w}$ finansowaniu majątku= kapitał włas$n y / a k t y w a^{2}$.

Na podstawie danych pochodzących ze sprawozdań finansowych badanych firm wyznaczono wartości funkcji dyskryminacyjnych oraz wartości najwrażliwszych predyktorów zagrożenia upadłością dla lat 2008-2014. Następnie, zgodnie z zasadami interpretacji wartości poszczególnych modeli, dokonano oceny ryzyka upadłości.

\section{Wyniki badań}

W tabelach o numerach od 1 do 3 zaprezentowano wyniki analizy dyskryminacyjnej dla wszystkich badanych przedsiębiorstw. Przyjęto następujące oznaczenia według odpowiednich kryteriów ustalonych dla poszczególnych badanych modeli:

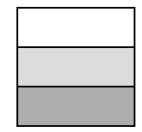

- spółka niezagrożona upadłością

- spółka w sytuacji niepewności (szara strefa)

- spółka zagrożona upadłością

\footnotetext{
${ }^{2}$ Wskaźniki: udziału kapitalu statego $w$ finansowaniu majatku, udziału kapitału wlasnego w finansowaniu majątku oraz pokrycia kosztów finansowych to również najlepsze predyktory upadłości dla firm handlowych.
} 
Model ZHCP wskazał na zagrożenie upadłością dla spółek: Duda SA (2009), Jago SA ${ }^{3}$ (2011) oraz Wilbo SA (2012). Pozostałe firmy w analizowanych latach uzyskały pozytywną weryfikację ich kondycji (por. tabela 1).

Tabela 1

Wyniki modelu wczesnego ostrzegania $\mathrm{Z}_{\mathrm{HCP}}$ (model poznański)

\begin{tabular}{|l|c|c|c|c|c|c|c|}
\hline SPÓŁKA & 2014 & 2013 & 2012 & 2011 & 2010 & 2009 & 2008 \\
\hline COLIAN & 4,711 & 4,882 & 5,502 & 4,602 & 5,332 & 4,611 & 3,901 \\
\hline DUDA & 2,913 & 2,536 & 2,167 & 3,096 & 2,872 & $-0,581$ & 0,563 \\
\hline GRAAL & 2,215 & 2,291 & 2,455 & 2,579 & 2,239 & 2,705 & 2,638 \\
\hline IDYKPOL & 4,136 & 2,298 & 1,899 & 3,289 & 4,611 & 2,881 & 2,357 \\
\hline JAGO & - & - & - & $-5,606$ & 1,525 & 3,617 & 5,331 \\
\hline KRUSZWICA & 5,816 & 2,846 & 1,385 & 1,429 & 1,747 & 2,508 & 1,693 \\
\hline $\begin{array}{l}\text { MAKARO- } \\
\text { NYPL }\end{array}$ & 3,470 & 3,068 & 1,865 & 2,221 & 3,175 & 3,690 & 1,964 \\
\hline MIESZKO & - & 2,980 & 3,606 & 4,813 & 5,156 & 3,050 & 4,704 \\
\hline MISPOL & - & - & 0,150 & 1,209 & 2,133 & 2,923 & 1,890 \\
\hline OTMUCHÓW & 3,182 & 2,914 & 3,111 & 3,250 & 5,394 & -4 & - \\
\hline PAMAPOL & 1,983 & 1,057 & 1,225 & 1,747 & 1,887 & 1,872 & 1,878 \\
\hline PEPEES & 2,367 & 3,208 & 3,062 & 3,455 & 4,315 & 2,623 & 3,042 \\
\hline SEKO & 4,369 & 4,241 & 3,130 & 2,590 & 3,685 & 5,357 & 4,261 \\
\hline WAWEL & 8,338 & 7,183 & 6,629 & 5,767 & 6,961 & 6,842 & 6,239 \\
\hline WILBO & 4,989 & 1,323 & $-3,415$ & 0,585 & 2,388 & 4,144 & 5,126 \\
\hline
\end{tabular}

Źródło: Obliczenia własne na podstawie danych ze sprawozdań finansowych.

Model $Z_{\mathrm{BP} 2}$ wykrył ryzyko upadłości w spółkach: Makarony Polskie SA (2008), Mispol SA (2011), Pamapol SA (2008), Pepees SA (2008, 2009 i 2014) oraz Wilbo SA (2012). Pozostałe przedsiębiorstwa zakwalifikował do „szarej strefy", z wyłączeniem spółki Wawel SA dla wszystkich analizowanych lat oraz Kruszwicy SA dla 2014 r. (por. tabela 2).

Model wczesnego ostrzegania $Z_{7 \text { INE PAN }}$ zasygnalizował zagrożenie upadłości w przedsiębiorstwach: Duda SA (2009), Jago SA ${ }^{4}$ (2010 i 2011), Mispol SA (2011 i 2012), Pamapol SA (2008 i 2013) oraz Wilbo SA (2011, 2012 i 2013). Inne spółki uzyskały pozytywną ocenę ich sytuacji finansowej w badanych latach (por. tabela 3).

\footnotetext{
${ }^{3}$ Według WWSWO dla przedsiębiorstw handlowych, opracowanego przez P. Antonowicza, model $\mathrm{Z}_{\mathrm{HCP}}$ zajmuje trzecią pozycję ze średnią skutecznością na poziomie 94,29\%. [Antonowicz 2007, s. 169].

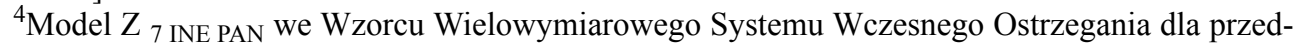
siębiorstw handlowych zajmuje pierwsze miejsce ze średnią sprawnością prognozy 95,71\%.
} 
Tabela 2

Wyniki modelu wczesnego ostrzegania $\mathrm{ZBP}_{2}$

\begin{tabular}{|l|c|c|c|c|c|c|c|}
\hline SPÓŁKA & 2014 & 2013 & 2012 & 2011 & 2010 & 2009 & 2008 \\
\hline COLIAN & 0,438 & 0,113 & 0,763 & 0,132 & 0,776 & 0,410 & $-0,275$ \\
\hline DUDA & 1,165 & 1,103 & 0,748 & 0,956 & 0,584 & $-0,662$ & $-0,582$ \\
\hline GRAAL & $-0,131$ & $-0,291$ & $-0,392$ & $-0,425$ & $-0,310$ & $-0,279$ & $-0,586$ \\
\hline IDYKPOL & 1,807 & 0,501 & 0,593 & 0,991 & 1,952 & 1,179 & 0,467 \\
\hline JAGO 5 & - & - & - & 1,711 & 1,202 & 0,146 & 0,063 \\
\hline KRUSZWICA & 4,508 & 1,774 & 0,075 & $-0,046$ & 0,159 & 1,074 & 0,712 \\
\hline MAKARONYPL & 0,032 & 0,151 & $-0,338$ & $-0,199$ & 0,068 & 0,146 & $-0,724$ \\
\hline MIESZKO & - & $-0,117$ & $-0,064$ & 0,202 & 1,178 & 0,786 & 0,994 \\
\hline MISPOL & - & - & $-0,365$ & $-0,761$ & 0,222 & 0,372 & 0,025 \\
\hline OTMUCHÓW & 0,086 & $-0,163$ & 0,046 & $-0,348$ & $-0,045$ & 0,789 & - \\
\hline PAMAPOL & $-0,123$ & $-0,334$ & $-0,566$ & $-0,577$ & $-0,224$ & $-0,437$ & $-0,757$ \\
\hline PEPEES & $-0,709$ & $-0,385$ & $-0,312$ & $-0,181$ & $-0,091$ & $-1,050$ & $-0,830$ \\
\hline SEKO & 0,302 & 0,289 & 0,174 & $-0,438$ & 0,385 & 1,243 & 0,772 \\
\hline WAWEL & 2,365 & 2,241 & 2,341 & 2,176 & 3,086 & 2,833 & 2,630 \\
\hline WILBO & 0,624 & 0,162 & $-1,471$ & $-0,373$ & $-0,092$ & 1,263 & 1,536 \\
\hline
\end{tabular}

Źródło: Obliczenia własne na podstawie danych ze sprawozdań finansowych.

Zakład przetwórstwa mięsnego Duda SA, dostrzeżony jako zagrożony przez $Z_{\text {HCP }}$ i $Z_{7}$ INE PAN, w 2009 r. miał spore kłopoty z pokryciem kosztów finansowych, bowiem odnotował wysoką stratę netto w kwocie 330,46 mln zł. Jednakże w kolejnych latach spółka ta poprawiła swój wynik finansowy i osiagała zysk, przy pewnych problemach jedynie w 2012 roku. W przypadku przedsiębiorstwa Jago SA, sąd w 2012 r. ogłosił w lutym upadłość układową, a w kwietniu likwidacyjną. Można zatem stwierdzić, że funkcja $\mathrm{Z}_{\mathrm{HCP}}$ $z$ rocznym, a model $Z_{7}$ INE PAN $z$ dwuletnim wyprzedzeniem zasygnalizowały kłopoty przedsiębiorstwa, choć pojawiły się one już wcześniej. Począwszy od 2008 r., spółka systematycznie odnotowywała stratę netto (od kwoty 4,38 mln zł w 2008 r. do 60,54 mln zł w 2011 r.) i miała trudności z terminowym spłacaniem zobowiązań.

Przedsiębiorstwo Wilbo SA od 2010 r. nie przynosiło zysków, realizując straty rzędu od 1,23 mln zł (2013 r.) do 30,66 mln zł (2012 r.) W lipcu 2012 r.

\footnotetext{
${ }^{5}$ Wzorzec Wielowymiarowego Systemu Wczesnego Ostrzegania dla przedsiębiorstw handlowych na drugiej pozycji plasuje model ZBP1 (średnia sprawność $=95,71 \%$ ), który dla spółki Jago SA osiąga wartości: 2008 r. $(-0,435) ; 2009$ r. $(-0,778) ; 2010$ r. $(-1,845)$ i 2011 r. $(-5,865)$. Zgodnie $\mathrm{z}$ interpretacją, funkcja w każdym roku sygnalizuje zagrożenie bankructwem dla tego przedsiębiorstwa, czyli wykazuje bardzo dobrą skuteczność.
} 
Tabela 3

Wyniki modelu wczesnego ostrzegania $Z_{7 \text { INE PAN }}$

\begin{tabular}{|l|c|c|c|c|c|c|c|}
\hline SPÓŁKA & 2014 & 2013 & 2012 & 2011 & 2010 & 2009 & 2008 \\
\hline COLIAN & 2,614 & 2,240 & 3,176 & 2,301 & 3,066 & 2,815 & 0,805 \\
\hline DUDA & 1,713 & 1,594 & 0,685 & 1,723 & 1,466 & $-4,693$ & 0,841 \\
\hline GRAAL & 1,369 & 1,254 & 1,318 & 1,236 & 1,125 & 1,178 & 1,006 \\
\hline IDYKPOL & 1,694 & 0,758 & 0,518 & 0,961 & 1,546 & 1,474 & 0,310 \\
\hline JAGO & - & - & - & $-14,175$ & $-3,070$ & 0,381 & 0,802 \\
\hline KRUSZWICA & 7,611 & 4,205 & 1,306 & 1,892 & 2,125 & 3,888 & 3,061 \\
\hline MAKARONYPL & 1,864 & 1,508 & 0,848 & 0,500 & 1,368 & 1,603 & 0,567 \\
\hline MIESZKO & - & 0,958 & 0,833 & 1,436 & 2,255 & 1,575 & 1,591 \\
\hline MISPOL & - & - & $-3,762$ & $-1,102$ & 0,944 & 0,822 & 0,638 \\
\hline OTMUCHÓW & 1,944 & 1,336 & 1,466 & 1,430 & 2,877 & 2,533 & - \\
\hline PAMAPOL & 0,341 & $-0,370$ & 0,001 & 0,204 & 0,409 & 0,366 & $-0,556$ \\
\hline PEPEES & 1,683 & 1,918 & 1,987 & 2,713 & 2,394 & 0,695 & 1,435 \\
\hline SEKO & 2,142 & 2,190 & 1,539 & 0,221 & 1,413 & 3,234 & 2,353 \\
\hline WAWEL & 6,837 & 6,211 & 5,642 & 5,234 & 6,328 & 5,633 & 5,196 \\
\hline WILBO & 0,549 & $-0,680$ & $-11,276$ & $-2,762$ & 0,187 & 2,603 & 3,485 \\
\hline
\end{tabular}

Źródło: Obliczenia własne na podstawie danych ze sprawozdań finansowych.

spółka Seko SA wycofała się z przejęcia Wilbo SA i zarząd przedsiębiorstwa złożył do sądu wniosek o ogłoszenie upadłości likwidacyjnej, który wycofał we wrześniu tego samego roku. Jednakże w marcu 2013 sąd na wniosek samej firmy ogłosił upadłość układową Wilbo SA ${ }^{6}$. Model wczesnego ostrzegania $\mathrm{Z}_{\mathrm{HCP}}$ zareagował $\mathrm{w}$ roku największych perturbacji przedsiębiorstwa, nie zasygnalizował jednak wcześniej nadciągających problemów. Zrobił to model

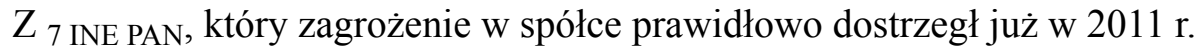

W 2008 r. spółka Makarony Polskie SA, zidentyfikowana przez $Z_{\mathrm{BP} 2}$, miała problem z pokryciem kosztów finansowych i odnotowała stratę netto w kwocie 2,78 mln zł. Z kolei przedsiębiorstwa Pamapol SA i Pepees SA, wykryte przez ten sam model, wykazywały w 2008 r. ujemne rentowności sprzedaży i majątku oraz straty netto odpowiednio 40,40 mln zł i 1,88 mln zł. Ponadto Pepees SA charakteryzowały: bardzo wysokie koszty własne sprzedaży, nieefektywne gospodarowanie aktywami oraz straty z działalności finansowej, rejestrowane w całym badanym okresie.

Model $Z_{\mathrm{BP} 2}$ zasygnalizował zagrożenie również w firmie Mispol SA w $2011 \mathrm{r}$. Spółka ta, wycofana z obrotu giełdowego w 2014 r. z powodu przejęcia przez

\footnotetext{
${ }^{6}$ W 2014 r. spółka wypracowała niewielki zysk, a w 2015 zawarła umowę na sprzedaż swoich wyrobów na Białorusi, stąd można żywić nadzieję na wyjście firmy Wilbo SA z kłopotów.
} 
litewski fundusz NDX energija, w latach 2011-2012 wykazywała ujemne rentowności sprzedaży, majątku i kapitału własnego, osiągając straty netto rzędu 27 i $40 \mathrm{mln} \mathrm{zl}$.

W tabelach od 4 do 7 zamieszczono obliczone wartości dla czterech najbardziej wrażliwych na zagrożenie upadłością wskaźników finansowych, ujętych we Wzorcu Wielowymiarowego Systemu Wczesnego Ostrzegania. Pogrubiona czcionką oznaczono poziomy wskaźników dla spółek, w przypadku których mo-

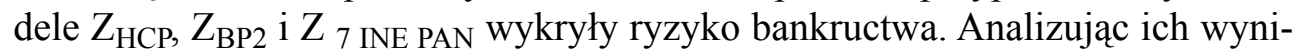
ki, można stwierdzić, że potwierdzają wszystkie zauważone problemy badanych przedsiębiorstw.

Wielkość wskaźnika udziału kapitału stałego w finansowaniu majątku poniżej 1 oznacza, że kapitał stały nie wystarcza do finansowania aktywów przedsiębiorstwa, a więc są one finansowane również przez kapitały obce krótkoterminowe. Zgodnie ze „złotą zasadą finansowania” przynajmniej aktywa trwałe powinny być $\mathrm{w}$ całości finansowane kapitałem stałym i większość badanych spółek spełnia tą relację. Im mniejsza wartość kapitału stałego w relacji do aktywów, tym przedsiębiorstwo może stanąć w obliczu niemożności bieżącego regulowania zobowiązań (por. tabela 4).

\section{Tabela 4}

Wartości wskaźnika udziału kapitału stałego w finansowaniu majątku

\begin{tabular}{|l|c|c|c|c|c|c|c|}
\hline SPÓŁKA & 2014 & 2013 & 2012 & 2011 & 2010 & 2009 & 2008 \\
\hline COLIAN & 0,775 & 0,772 & 0,825 & 0,771 & 0,818 & 0,759 & 0,723 \\
\hline DUDA & 0,691 & 0,646 & 0,626 & 0,695 & 0,657 & $\mathbf{0 , 4 6 2}$ & $\mathbf{0 , 3 7 5}$ \\
\hline GRAAL & 0,511 & 0,520 & 0,533 & 0,577 & 0,536 & 0,571 & 0,590 \\
\hline IDYKPOL & 0,749 & 0,580 & 0,530 & 0,668 & 0,783 & 0,635 & 0,627 \\
\hline JAGO & - & - & - & $\mathbf{- 0 , 3 6 1}$ & $\mathbf{0 , 5 1 4}$ & 0,648 & 0,794 \\
\hline KRUSZWICA & 0,842 & 0,682 & 0,522 & 0,505 & 0,565 & 0,622 & 0,471 \\
\hline MAKARONYPL & 0,718 & 0,718 & 0,570 & 0,637 & 0,695 & 0,774 & 0,580 \\
\hline MIESZKO & - & 0,581 & 0,676 & 0,767 & 0,728 & 0,507 & 0,699 \\
\hline MISPOL & - & - & $\mathbf{0 , 4 6 9}$ & $\mathbf{0 , 4 9 5}$ & 0,510 & 0,629 & 0,443 \\
\hline OTMUCHÓW & 0,650 & 0,639 & 0,633 & 0,661 & 0,755 & 0,644 & - \\
\hline PAMAPOL & 0,502 & $\mathbf{0 , 4 3 3}$ & 0,415 & 0,482 & 0,504 & 0,531 & $\mathbf{0 , 5 6 5}$ \\
\hline PEPEES & 0,627 & 0,700 & 0,686 & 0,694 & 0,784 & 0,720 & 0,735 \\
\hline SEKO & 0,730 & 0,728 & 0,692 & 0,705 & 0,739 & 0,745 & 0,697 \\
\hline WAWEL & 0,804 & 0,769 & 0,756 & 0,734 & 0,792 & 0,794 & 0,784 \\
\hline WILBO & 0,783 & $\mathbf{0 , 4 6 3}$ & $\mathbf{0 , 2 3 1}$ & $\mathbf{0 , 4 9 6}$ & 0,587 & 0,725 & 0,753 \\
\hline
\end{tabular}

Źródło: Obliczenia własne na podstawie danych ze sprawozdań finansowych. 
Wskaźnik pokrycia kosztów finansowych wykorzystywany jest do analizy zadłużenia spółki. Pokazuje w jakim stopniu zyski operacyjne spółki mogą ulec obniżeniu, aby zostały pokryte koszty finansowe. Im większa wartość wskaźnika, tym większe bezpieczeństwo finansowe firmy. Ujemna wartość wskaźnika świadczy o poniesionej stracie przez przedsiębiorstwo (por. tabela 5).

\section{Tabela 5}

Wartości wskaźnika pokrycia kosztów finansowych

\begin{tabular}{|l|c|c|c|c|c|c|c|}
\hline SPÓŁKA & 2014 & 2013 & 2012 & 2011 & 2010 & 2009 & 2008 \\
\hline COLIAN & 3,470 & 3,033 & 2,683 & 6,402 & 11,430 & 7,639 & $\mathbf{- 2 , 2 8 2}$ \\
\hline DUDA & 2,348 & 2,304 & 0,505 & 2,413 & 2,246 & $\mathbf{- 1 , 7 7 0}$ & 0,805 \\
\hline GRAAL & 2,590 & 2,373 & 2,150 & 1,476 & 1,632 & 1,596 & 1,000 \\
\hline IDYKPOL & 7,169 & 1,595 & 0,675 & 1,654 & 1,661 & 2,729 & 0,060 \\
\hline JAGO & - & - & - & $\mathbf{- 8 , 1 2 9}$ & $\mathbf{- 3 , 5 1 9}$ & $-1,116$ & $-1,456$ \\
\hline KRUSZWICA & $\mathbf{2 9 , 8 8 4}$ & $\mathbf{8 , 1 6 5}$ & 0,544 & 1,685 & 3,412 & 7,153 & 2,907 \\
\hline MAKARONYPL & 3,133 & 1,728 & 0,525 & $\mathbf{- 0 , 0 7 3}$ & 2,164 & 2,142 & $\mathbf{- 0 , 7 1 2}$ \\
\hline MIESZKO & - & 1,966 & 1,879 & 3,694 & 5,835 & 3,953 & 2,219 \\
\hline MISPOL & - & - & $\mathbf{- 5 , 1 6 8}$ & $\mathbf{- 2 , 2 1 7}$ & 0,948 & 0,499 & 0,613 \\
\hline OTMUCHÓW & 5,219 & 1,715 & 2,606 & 5,446 & 9,973 & 14,563 & - \\
\hline PAMAPOL & 0,842 & $\mathbf{- 0 , 3 5 6}$ & 0,005 & 0,815 & 1,245 & 0,736 & $\mathbf{- 0 , 5 7 6}$ \\
\hline PEPEES & 4,396 & $\mathbf{1 , 5 0 4}$ & 2,160 & $\mathbf{7 , 7 8 5}$ & 1,479 & $\mathbf{- 1 , 6 3 1}$ & $\mathbf{- 2 , 4 4 6}$ \\
\hline SEKO & 8,000 & $\mathbf{7 , 7 4 0}$ & $\mathbf{3 , 2 9 0}$ & $\mathbf{- 3 , 7 4 5}$ & 11,678 & 18,645 & $\mathbf{2 , 7 1 6}$ \\
\hline WAWEL & 120,942 & $\mathbf{4 6 3 , 8 2 1}$ & $\mathbf{6 3 4 , 7 5 4}$ & 144,438 & 62,528 & 44,729 & 50,816 \\
\hline WILBO & 0,944 & $\mathbf{- 0 , 5 2 2}$ & $\mathbf{- 7 , 3 3 3}$ & $\mathbf{- 1 , 2 3 3}$ & $\mathbf{- 1 , 1 6 4}$ & 0,385 & 6,144 \\
\hline
\end{tabular}

Źródło: Obliczenia własne na podstawie danych ze sprawozdań finansowych.

Wskaźnik płynności gotówkowej informuje o tym, jaka część zobowiązań bieżących może być uregulowana bez zwłoki, gdyby stały się one w danym momencie wymagalne. $Z$ doświadczenia gospodarki wynika, że środki pieniężne powinny stanowić co najmniej $16-20 \%$ zobowiązań bieżących, żeby przedsiębiorstwo było zdolne do ich sprawnego regulowania (por. tabela 6).

Wskaźnik badający udział kapitału własnego w finansowaniu majątku wskazuje na poziom zadłużenia finansowego przedsiębiorstwa. Duża wartość tego wskaźnika świadczy o niskiej dźwigni finansowej wykorzystywanej przez firmę, czyli o małym zaangażowaniu kapitałów obcych - kredytów i zobowiązań. Przy wskaźniku kapitałowym równym 1, finansowanie firmy odbywa się wyłącznie za pomocą środków własnych (por. tabela 7). 
126

Tabela 6

Wartości wskaźnika płynności gotówkowej

\begin{tabular}{|l|c|c|c|c|c|c|c|}
\hline SPÓŁKA & 2014 & 2013 & 2012 & 2011 & 2010 & 2009 & 2008 \\
\hline COLIAN & $15,17 \%$ & $16,78 \%$ & $20,08 \%$ & $21,66 \%$ & $7,78 \%$ & $13,71 \%$ & $\mathbf{2 , 2 1 \%}$ \\
\hline DUDA & $21,82 \%$ & $8,41 \%$ & $4,99 \%$ & $8,76 \%$ & $15,88 \%$ & $\mathbf{6 , 7 3} \%$ & $2,55 \%$ \\
\hline GRAAL & $3,77 \%$ & $8,19 \%$ & $6,06 \%$ & $3,12 \%$ & $1,16 \%$ & $1,35 \%$ & $4,36 \%$ \\
\hline IDYKPOL & $3,70 \%$ & $4,65 \%$ & $1,12 \%$ & $2,64 \%$ & $2,29 \%$ & $6,69 \%$ & $13,68 \%$ \\
\hline JAGO & - & - & - & $\mathbf{4 , 2 3} \%$ & $\mathbf{1 , 4 9} \%$ & $6,82 \%$ & $5,51 \%$ \\
\hline KRUSZWICA & $92,21 \%$ & $0,39 \%$ & $0,39 \%$ & $4,10 \%$ & $0,18 \%$ & $2,40 \%$ & $0,37 \%$ \\
\hline MAKARONYPL & $4,29 \%$ & $3,68 \%$ & $1,58 \%$ & $\mathbf{1 , 9 0} \%$ & $0,90 \%$ & $3,51 \%$ & $2,69 \%$ \\
\hline MIESZKO & - & $7,54 \%$ & $3,26 \%$ & $5,16 \%$ & $4,27 \%$ & $1,94 \%$ & $1,56 \%$ \\
\hline MISPOL & - & - & $\mathbf{1 , 2 1} \%$ & $\mathbf{1 , 3 4} \%$ & $6,41 \%$ & $6,13 \%$ & $2,74 \%$ \\
\hline OTMUCHÓW & $4,38 \%$ & $5,47 \%$ & $4,28 \%$ & $1,59 \%$ & $47,29 \%$ & $1,55 \%$ & - \\
\hline PAMAPOL & $2,08 \%$ & $\mathbf{1 , 3 8} \%$ & $\mathbf{7 , 0 3} \%$ & $0,74 \%$ & $0,75 \%$ & $1,25 \%$ & $\mathbf{0 , 9 7 \%}$ \\
\hline PEPEES & $3,47 \%$ & $34,33 \%$ & $25,74 \%$ & $14,00 \%$ & $63,80 \%$ & $\mathbf{2 8 , 1 5 \%}$ & $\mathbf{2 2 , 6 4 \%}$ \\
\hline SEKO & $54,12 \%$ & $43,82 \%$ & $2,90 \%$ & $2,58 \%$ & $4,84 \%$ & $65,47 \%$ & $35,88 \%$ \\
\hline WAWEL & $99,52 \%$ & $58,05 \%$ & $33,16 \%$ & $5,23 \%$ & $8,09 \%$ & $18,56 \%$ & $1,14 \%$ \\
\hline WILBO & $3,87 \%$ & $\mathbf{3 , 7 1} \%$ & $\mathbf{3 , 7 7} \%$ & $\mathbf{1 , 0 3} \%$ & $2,56 \%$ & $2,02 \%$ & $11,34 \%$ \\
\hline
\end{tabular}

Źródło: Obliczenia własne na podstawie danych ze sprawozdań finansowych.

Tabela 7

Wartości wskaźnika udziału kapitału własnego w finansowaniu majątku

\begin{tabular}{|l|c|c|c|c|c|c|c|}
\hline SPÓŁKA & 2014 & 2013 & 2012 & 2011 & 2010 & 2009 & 2008 \\
\hline COLIAN & 0,738 & 0,680 & 0,779 & 0,692 & 0,743 & 0,695 & $\mathbf{0 , 6 4 1}$ \\
\hline DUDA & 0,529 & 0,491 & 0,439 & 0,455 & 0,395 & $\mathbf{0 , 3 0 2}$ & 0,347 \\
\hline GRAAL & 0,432 & 0,444 & 0,457 & 0,464 & 0,439 & 0,423 & 0,426 \\
\hline IDYKPOL & 0,408 & 0,372 & 0,350 & 0,358 & 0,406 & 0,410 & 0,373 \\
\hline JAGO & - & - & - & $\mathbf{- 0 , 4 0 8}$ & $\mathbf{0 , 2 3 3}$ & 0,431 & 0,485 \\
\hline KRUSZWICA & 0,834 & 0,676 & 0,515 & 0,499 & 0,544 & 0,593 & 0,435 \\
\hline MAKARONYPL & 0,533 & 0,512 & 0,473 & $\mathbf{0 , 4 1 8}$ & 0,488 & 0,519 & 0,516 \\
\hline MIESZKO & - & 0,345 & 0,303 & 0,314 & 0,491 & 0,461 & 0,434 \\
\hline MISPOL & - & - & $\mathbf{0 , 3 0 6}$ & $\mathbf{0 , 3 5 2}$ & 0,452 & 0,429 & 0,386 \\
\hline OTMUCHÓW & 0,561 & 0,519 & 0,479 & 0,471 & 0,608 & 0,422 & - \\
\hline PAMAPOL & 0,284 & $\mathbf{0 , 2 8 8}$ & 0,255 & 0,246 & 0,270 & 0,279 & $\mathbf{0 , 2 7 6}$ \\
\hline PEPEES & 0,556 & 0,608 & 0,586 & 0,584 & 0,661 & $\mathbf{0 , 5 8 8}$ & $\mathbf{0 , 6 1 4}$ \\
\hline SEKO & 0,512 & 0,494 & 0,495 & 0,471 & 0,552 & 0,665 & 0,589 \\
\hline WAWEL & 0,774 & 0,739 & 0,715 & 0,695 & 0,747 & 0,749 & 0,759 \\
\hline WILBO & 0,146 & $\mathbf{0 , 1 4 5}$ & $\mathbf{0 , 1 5 5}$ & $\mathbf{0 , 4 1 9}$ & 0,495 & 0,693 & 0,720 \\
\hline
\end{tabular}

Źródło: Obliczenia własne. 


\section{Podsumowanie}

W świetle powyższego należy zwrócić uwagę, że w przypadku omawianych modeli oraz wskaźników finansowych z Wzorca Wielowymiarowego Systemu Wczesnego Ostrzegania dla spółek produkcyjnych sektora spożywczego:

1. Model $Z_{7}$ INE PAN wykazał się dużą wrażliwością na wykrywanie zagrożeń upadłością i z pewnym wyprzedzeniem alarmował o potencjalnych i rzeczywistych kłopotach spółek. Funkcja $Z_{\mathrm{HCP}}$ wskazywała firmy, jako zagrożone bankructwem, zbyt późno, bo dopiero w roku w którym tą upadłość ogłoszono. Oba modele odwołują się w wykorzystywanych wskaźnikach do szeroko pojętych aktywów. Jednak bywa, że dopiero w momencie ogłaszania upadłości duża część aktywów przedsiębiorstwa (np. należności i aktywów trwałych) zostaje poddana weryfikacji co do ich rzeczywistej wartości. Nagle, z dnia na dzień, dokonywane są odpisy aktualizujące majątek i pogarsza się wynik finansowy. Sprawozdanie finansowe spółki, sporządzone w najlepszej wierze, może nie odzwierciedlać istotnych zagrożeń wynikających np. z załamania się płatności w łańcuchu odbiorców dostaw.

2. Model $Z_{\mathrm{BP} 2}$ był najbardziej wyczulony na ryzyko upadłości i 13 z 15 badanych firm, w całym analizowanym okresie, zakwalifikował albo do tzw. szarej strefy albo do przedsiębiorstw zagrożonych bankructwem. Funkcja ta w przeważającej części odwołuje się do wartości z rachunku zysków i strat. Ta wrażliwość może wynikać z wykorzystania wskaźnika, odnoszącego się wprost do ponoszonych przez firmę kosztów, który informuje o cyklu realizacji zobowiązań w stosunku do kosztów operacyjnych. Ponadto model ten uwzględnia zmiany sumy bilansowej w czasie.

3. Wskaźniki będące najwrażliwszymi predyktorami upadłości nawiązują do zdolności pokrycia zobowiązań spółki przez zakumulowany majątek. Ich wartości w dużej mierze potwierdzają wyniki analizowanych modeli wczesnego ostrzegania.

4. Każda z analizowanych funkcji dyskryminacyjnych oparta jest na innym zestawie wskaźników i lepiej bądź gorzej analizuje stan finansów spółek sektora spożywczego. Aby ocenić dany model dyskryminacyjny, należy koncentrować się na dynamice wyników finansowych danego przedsiębiorstwa $z$ lat ubiegłych. Dopiero taka analiza pomoże wytypować długotrwałe czynniki warunkujące działalność przedsiębiorstwa, które w przyszłości moga spowodować kłopoty finansowe. 


\section{Literatura}

ANTONOWICZ P.: Metody oceny i prognoza kondycji ekonomiczno-finansowej przedsiębiorstw, ODiDK, Gdańsk 2007.

GAJDKA J., STOS D.: Wykorzystanie analizy dyskryminacyjnej w ocenie kondycji finansowej przedsiębiorstw, praca zbiorowa pod red. R. Borowieckiego: Restrukturyzacja w procesie przekształceń i rozwoju przedsiębiorstw, AE, Kraków 1996.

GRUSZCZYŃSKI M.: Modele mikroekonometrii $w$ analizie i prognozowaniu zagrożenia finansowego przedsiębiorstw, Instytut Nauk Ekonomicznych Polskiej Akademii Nauk, Working Papers Nr 34, Warszawa 2003.

HADASIK D.: Upadłość przedsiębiorstw w Polsce i metody jej prognozowania, ZN AE w Poznaniu, Seria II, nr 153, Poznań 1998.

HAMROL M., CHODAKOWSKI J.: Prognozowanie zagrożenia finansowego przedsiębiorstwa. Wartość predykcyjna polskich modeli analizy dyskryminacyjnej, Badania Operacyjne i Decyzje nr 3, Wrocław 2008.

HAMROL M., CZAJKA B., PIECHOCKI M.: Upadtość przedsiębiorstwa - model analizy dyskryminacyjnej, „Przegląd Organizacji” nr 6, Warszawa 2004.

HOŁDA A.: Prognozowanie bankructwa jednostki w warunkach gospodarki polskiej z wykorzystaniem funkcji dyskryminacyjnej $Z_{H}$, Rachunkowość nr 5, Warszawa 2001.

KISIELIŃSKA J.: Modele klasyfikacyjne prognozowania sytuacji finansowej gospodarstw rolniczych, Wydawnictwo SGGW, Warszawa 2008.

KISIELIŃSKA J., WASZKOWSKI A.: Polskie modele do prognozowania bankructwa przedsiębiorstw i ich weryfikacja, EiOGŻ nr 82, Wydawnictwo SGGW, Warszawa 2010.

LICHOTA W.: Metody wczesnego ostrzegania o zmianach sytuacji finansowej przedsiębiorstw, Wiadomości Statystyczne nr 10, Warszawa 2009.

MĄCZYŃSKA E., ZAWADZKI M.: Dyskryminacyjne modele predykcji bankructwa przedsiębiorstw, Ekonomista nr 2, Warszawa 2006.

MEJER D.: Analiza dyskryminacyjna, Bank nr 06, Warszawa 2000.

PRUSAK B.: Nowoczesne metody prognozowania zagrożenia finansowego przedsiębiorstwa, Difin, Warszawa 2005.

RAPORT COFACE nt. upadłości firm w 2014 r., www.coface.pl.

RAPORT z konferencji PAIiIZ Motor polskiej gospodarki-branża spożywcza, styczeń 2015, http://www.paiz.gov.pl/20150112/motor_polskiej_gospodarki_sektor_spozywczy.

SOJAK S., STAWICKI J.: Wykorzystanie metod taksonomicznych do oceny kondycji ekonomicznej przedsiębiorstw, „Zeszyty Teoretyczne Rachunkowości” t. 3 (59), Warszawa 2001.

WIERZBA D., Wczesne wykrywanie przedsiębiorstw zagrożonych upadtościq na podstawie analizy wskaźników finansowych - teoria i badania empiryczne, ZN WSE - I w Warszawie nr 8, Warszawa 2000.

\section{Abstrakt}

Przedsiębiorstwa, w warunkach konkurencji wolnorynkowej, powinny szybko i elastycznie reagować na zmiany i perturbacje w niestabilnej gospodarce. Podmioty, które nie są w stanie nadążyć za bieżącymi zmianami wchodzą na ścieżkę kryzysu w firmie, której ostatnim etapem może stać się upadłość. 
W pracy przedstawiono próbę wykorzystania i oceny trzech polskich modeli wielowymiarowej analizy dyskryminacyjnej oraz najwrażliwszych wskaźników finansowych, zaproponowanych w WWSWO P. Antonowicza (2007), w zakresie prognozowania zagrożenia upadłością. Analizę przeprowadzono dla lat 2008-2014. Do badania wybrano 15 firm sektora spożywczego, notowanych na rynku głównym GPW w Warszawie, których rachunek zysków i strat sporządzany jest w układzie kalkulacyjnym.

Słowa kluczowe: Polski rynek spożywczy, firma spożywcza, wskaźniki finansowe, analiza dyskryminacyjna

\section{Application of multivariate discriminant analysis for prediction of bankruptcy of selected food industry companies}

\section{Abstract}

On the free market, the companies should quickly and flexibly react to changes and perturbations in the unstable economy. Entities, which are not able to keep up with the changes, enter the path of crisis, whose last stage may be bankruptcy.

The paper attempts to use and evaluate three of Polish models of the multivariate discriminant analysis and the most sensitive financial ratios proposed in the prediction models by P. Antonowicz (2007) in forecasting the risk of bankruptcy. The analysis was conducted for the years 2008-2014. 15 food industry companies, listed on the main market of the Warsaw Stock Exchange and preparing profit and loss account with the use of the calculation model, were analysed.

Key words: Polish food market, food company, financial ratios, discriminant analysis 